\title{
KUALITAS JARINGAN PADA JARINGAN VIRTUAL LOCAL AREA NETWORK (VLAN) YANG MENERAPKAN LINUX TERMINAL SERVER PROJECT (LTSP)
}

\author{
Badia Raja, Lipur Sugiyanta \\ Program Studi Pendidikan Teknik Informatika dan Komputer \\ Universitas Negeri Jakarta \\ badia.radja@gmail.com, lipurs@unj.ac.id
}

\begin{abstract}
Abstrak
Virtual Local Area Network (VLAN) merupakan sebuah teknik dalam jaringan komputer untuk menciptakan beberapa jaringan yang berbeda tetapi masih merupakan sebuah jaringan lokal yang tidak terbatas pada lokasi fisik seperti LAN sedangkan Linux Terminal Server Project (LTSP) merupakan sebuah teknik terminal server yang dapat memperbanyak workstation dengan hanya menggunakan sebuah Linux server. Dalam membangun sebuah jaringan komputer perlu memperhatikan beberapa hal dan salah satunya adalah kualitas jaringan dari jaringan yang dibangun. Pada penelitian ini bertujuan untuk mengetahui pengaruh jumlah client terhadap kualitas jaringan berdasarkan parameter delay dan packet loss pada jaringan VLAN yang menerapkan LTSP. Oleh karena itu, penelitian ini menggunakan jenis metode penelitian kualitatif dengan memperhatikan standar yang digunakan dalam penelitian yaitu standar International Telecommunication Union - Telecommunication (ITU-T). Penerapan penelitian ini menggunakan sistem operasi pada server adalah Ubuntu Desktop 14.04 LTS. Berdasarkan dari hasil penelitian yang ditemukan dapat disimpulkan bahwa benar terbukti bahwa makin banyak client yang dilayani oleh server maka akan menurunkan kualitas jaringan berdasarkan parameter Quality of Service (QoS) yang digunakan yaitu delay dan packet loss.
\end{abstract}

Kata kunci: VLAN, LTSP, QoS 


\section{PENDAHULUAN}

Pada awalnya komputer pribadi ( stand alone ), menggunakan program sesuai dengan kebutuhan pengguna tanpa ada mekanisme komunikasi data antar-komputer. Seiring dengan adanya revolusi di bidang teknologi informasi, kini komputer dapat bekerja dalam sistem jaringan komunikasi baik jarak dekat maupun jarak jauh, seperti yang terimplementasikan dalam jaringan lokal maupun jaringan global.

Diperlukan sebuah teknologi untuk mengurangi biaya dari kebutuhan dalam menggunakan komputer dalam jumlah yang banyak. Banyak cara yang dapat dilakukan untuk mengatasi hal tersebut dan salah satu teknologi untuk merealisasikannya adalah dengan melakukan PCCloning atau PC diskless dalam penggunaan komputer dalam jumlah banyak dalam satu ruangan.

Model PC-Cloning yang telah dikenal saat ini diantaranya Linux Terminal Server Project (LTSP), Userful, dan N-Computing. Di antara tiga jenis tersebut yang banyak digunakan adalah LTSP. LTSP merupakan pengembangan yang dilakukan untuk mengatasi kebutuhan masyarakat saat ini yang ingin mengadakan penggunaan komputer dalam jumlah banyak tapi tetap mempertahankan kualitas yang diberikan. LTSP (Linux Terminal Server Project) sendiri adalah aplikasi untuk membangun jaringan thin-client atau diskless. Client-server LTSP disebut thin client karena komputer client hanya digunakan untuk menjalankan sistem operasi minimal, sedangkan semua program aplikasi dijalankan di server. Jaringan LTSP juga disebut diskless, karena komputer client tidak bekerja dengan harddisk sendiri. LTSP pada intinya adalah satu kumpulan script yang memungkinkan kita menampilkan layar server di client. LTSP menyediakan suatu cara untuk menggunakan komputer kerja murah baik sebagai terminal yang berbasis grafis maupun yang berbasis teks pada server GNU/Linux. Dengan menggunakan LTSP kita dapat menggunakan low end PC dan membuang hardisk, floppy, dan $\mathrm{CD}$ ROM nya, dengan menambahkan LAN card yang dapat di-boot. Segala permasalahan yang terjadi dapat diatasi dengan mudah karena segalanya dapat diperbaiki hanya di server saja.
Membangun LTSP kebanyakan saat ini menerapkan jaringan lokal sebagai dasar untuk memenuhi kebutuhan menggunakan komputer dalam jumlah banyak namun perlu diketahui di dalam jaringan lokal ada istilah Virtual Local Area Network (VLAN) yang juga lagi banyak diterapkan di banyak tempat yang akan membangun jaringan komputer. VLAN merupakan suatu model jaringan yang tidak terbatas pada lokasi fisik seperti LAN, hal ini mengakibatkan suatu jaringan dapat dikonfigurasi secara virtual tanpa harus menuruti lokasi fisik peralatan. Penggunaan VLAN akan membuat pengaturan jaringan menjadi sangat fleksibel dimana dapat dibuat segmen yang bergantung pada organisasi atau departemen, tanpa bergantung pada lokasi workstation. Keuntungan menggunakan VLAN antara lain: keamanan untuk mengontrol terhadap setiap port dan user dimana user tidak akan bisa lagi dengan leluasa untuk menghubungkan workstation mereka ke sembarang port pada swich dan memperoleh akses ke sumber daya jaringan, dapat melakukan penghematan biaya karena tidak diperlukannya biaya yang mahal untuk peningkatan jaringan dan efisiensi penggunaan bandwidth dan uplink yang tersedia, dan performa tinggi dengan membagi jaringan layer 2 menjadi beberapa worksgroup secara logik (broadcast domain) mengurangi trafik yang tidak diperlukan pada jaringan.

Berdasarkan hal-hal tersebut maka adanya suatu gagasan perlu dilakukan membangun suatu VLAN yang di dalamnya menerapkan LTSP untuk mengetahui kualitas jaringan yang dapat diketahui melalui parameter delay dan packet loss sehingga akan membantu permasalahan setiap orang yang menginginkan suatu jaringan komputer yang benarbenar dapat digunakan untuk dalam jangka waktu yang lama.

\section{KAJIAN TEORI}

\section{PC-Cloning}

Mumpuni dan Wardono (2003: 89) mendefinisikan PC-Cloning sebagai suatu sistem yang diterapkan pada jaringan komputer, digunakan untuk mentransfer kemampuan hardware server ke seluruh client yang terkoneksi atau bisa pula 
didefinisikan sebagai suatu sistem yang diterapkan pada jaringan komputer, di mana seluruh proses kerja dalam jaringan tersebut ditangani oleh server sepenuhnya dengan menggunakan utilitas tertentu (Mumpuni dan Wardono, 2003: 89)

PC-Cloning yang dikenal saat ini memiliki beberapa jenis, antara lain: Userful, N-Computing, dan LTSP.

\section{Userful}

Userful pun menawarkan fitur PC lengkap termasuk tampilan video berkualitas tinggi hanya dengan menggunakan perangkat keras standar. Dengan menggunakan desktop virtual, para pengguna diperkirakan bisa menghemat biaya sebesar $60 \%$ untuk pembelian perangkat keras, $80 \%$ listrik setiap tahun, dan juga biaya perawatan rutin. Program ini memungkinkan 10 user bisa bekerja secara bersamaan hanya dengan menggunakan satu komputer. Mereka hanya cukup menambahkan monitor, mouse dan keyboard ekstra.

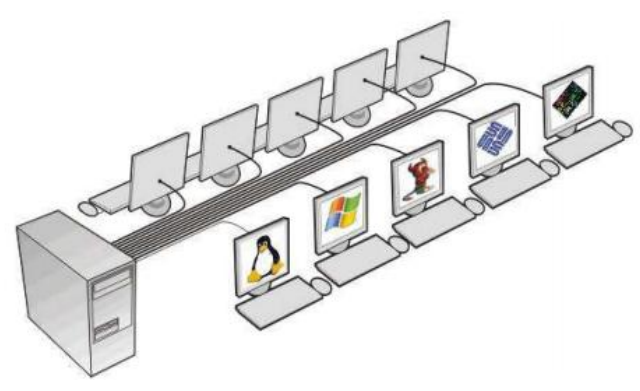

Gambar 1. Skema Userful

\section{N-Computing}

Ncomputing adalah terminal atau pusat pertama komputer di dunia yang tidak membutuhkan CPU, harddrive, atau CD-ROM dan dapat dipergunakan sama seperti PC biasa (Lihat Gambar 2.3). Dengan Ncomputing exclusive UTMA (Ultra Thin MultiAccess) teknologi, Ncomputing dapat mengekspansi PC anda sampai 10 terminal komputer. (sampai 30 dengan Windows Server 2003 atau 2000 Server. Unlimited terminals dengan operating sistem Linux tertentu). Cocok untuk di kantoran dan di laboratorium sekolah.

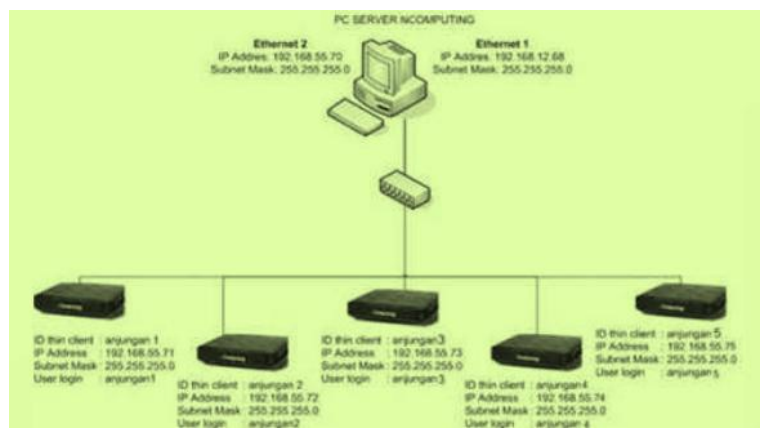

Gambar 2. Skema N-Computing

\section{Linux Terminal Server Project (LTSP)}

Linux Terminal Server Project (LTSP) memberikan cara yang mudah untuk menggunakan terminal yang murah dengan interface grafik maupun karakter pada Linux Server. Dengan menggunakan LTSP, kita dapat menggunakan low end PC dan membuang harddisk, floppy, dan CD-ROOM dengan menambahkan LAN Card yang dapat di boot. Pada saat booting, sebuah diskless workstation akan memperoleh IP address dan sistem operasi (kernel) dari server, kemudian mount root filesystem melalui server menggunakan protocol Network File System (NFS).

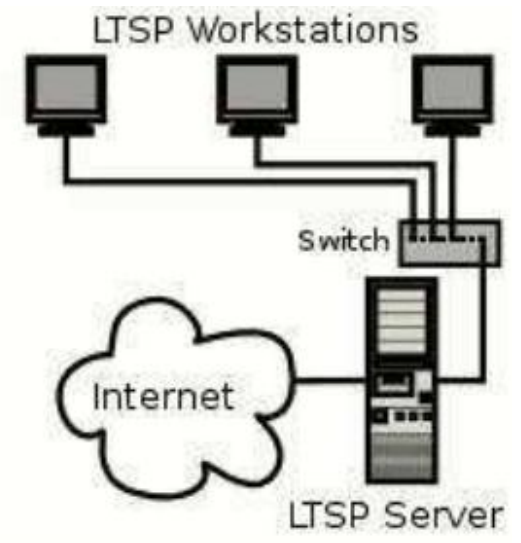

Gambar 3. Skema LTSP

Jaringan Komputer

Secara eksplisit pengertian jaringan komputer sebagaimana dikutip dari Situs Techi Wire House bahwa "Jaringan komputer adalah kumpulan dua atau lebih komputer yang terhubung dan ketika komputer ini bergabung dalam jaringan, maka orang dapat berbagi file dan peripheral seperti modem, printer, tape drive cadangan, atau CD-ROM drive. 
Secara luas jaringan komputer bisa terhubung ke beberapa lokasi yang terhubung dengan menggunakan layanan yang tersedia dari Perusahaan penyedia Layanan Internet, sehingga jaringan komputer dapat mengirim e-mail, berbagi link ke internet global, atau melakukan konferensi video secara real time dengan pengguna jarak jauh lainnya."

Menurut Izaas el Said, seorang pakar jaringan komputer mengatakan pengertian jaringan komputer adalah sebuah sistem di mana komputer yang terhubung untuk berbagi informasi dan sumber daya. Koneksi dapat dilakukan sebagai peer-to-peer atau client/server, biasanya hubungan antara komputer ini lebih cepat dari umumnya koneksi internet.

Menurut Cage, chief researcher dari Sun Microsystems (1984), jaringan komputer adalah hubungan dari dua atau lebih komputer, dan perangkat lainnya (seperti printer, hard drive eksternal, modem, dan router), yang terhubung bersama sehingga mereka dapat berkomunikasi saling berkomunikasi/ perintah pertukaran dan berbagi data, perangkat keras dan sumber daya lainnya (Cage, 1984).

\section{Local Area Network (LAN)}

Local Area Network atau LAN, merupakan suatu Jenis Jaringan Komputer dengan mencakup wilayah lokal. Dengan menggunakan berbagai perangkat jaringan yang cukup sederhana dan populer, seperti menggunakan kabel UTP (Unshielded Twisted-Pair), Hub, Switch, Router, dan lain sebagainya.Contoh dari jaringan LAN seperti komputer-komputer yang saling terhubung di sekolah, di perusahaan, Warnet, maupun antar rumah tetangga yang masih mencakup wilayah LAN.

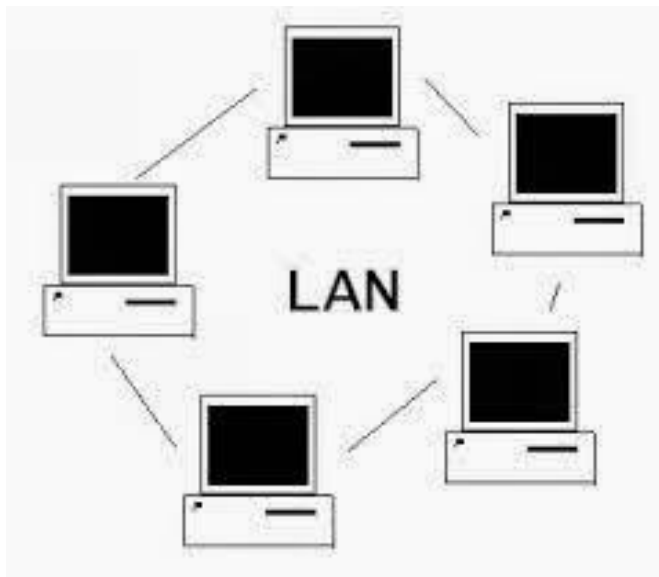

Gambar 4. Skema Jaringan LAN

\section{Virtual Local Area Network (VLAN)}

VLAN merupakan suatu model jaringan yang tidak terbatas pada lokasi fisik seperti LAN, hal ini mengakibatkan suatu network dapat dikonfigurasi secara virtual tanpa harus menuruti lokasi fisik peralatan. Penggunaan VLAN akan membuat pengaturan jaringan menjadi sangat fleksibel dimana dapat dibuat segmen yang bergantung pada organisasi atau departemen, tanpa bergantung pada lokasi workstation.

VLAN diklasifikasikan berdasarkan metode (tipe) yang digunakan untuk mengklasifikasikannya, baik menggunakan port, MAC addresses dan sebagainya.

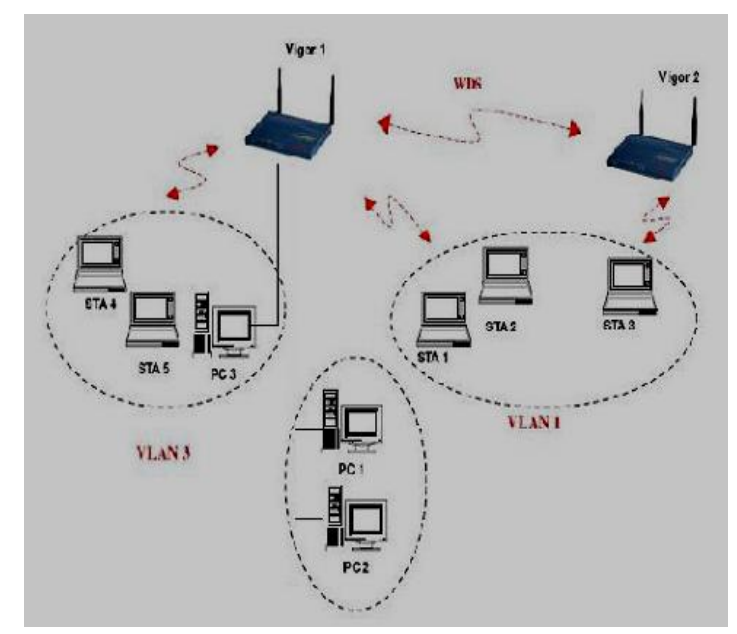

Gambar 5. Skema VLAN

VLSM adalah suatu teknik untuk mengurangi jumlah ruang spasi terbuang. Sebagai ganti memberi suatu kelas lengkap A, B atau C 
jaringan kepada suatu Admin, dapat diberikan suatu subnet ke seseorang, dan dia dapat lebih lanjut membagi lebih lanjut membagi subnet ke dalam beberapa subnets.

\section{Metropolitan Area Network (MAN)}

Metropolitan Area Network atau MAN, merupakan Jenis Jaringan Komputer yang lebih luas dan lebih canggih dari Jenis Jaringan Komputer LAN. Disebut Metropolitan Area Network karena Jenis Jaringan Komputer MAN ini biasa digunakan untuk menghubungkan jaringan komputer dari suatu kota ke kota lainnya. Untuk dapat membuat suatu jaringan MAN, biasanya diperlukan adanya operator telekomunikasi untuk menghubungkan antar jaringan komputer. Contohnya seperti jaringan Depdiknas antar kota atau wilayah dan juga jaringan mall-mall modern yang saling berhubungan antar kota.

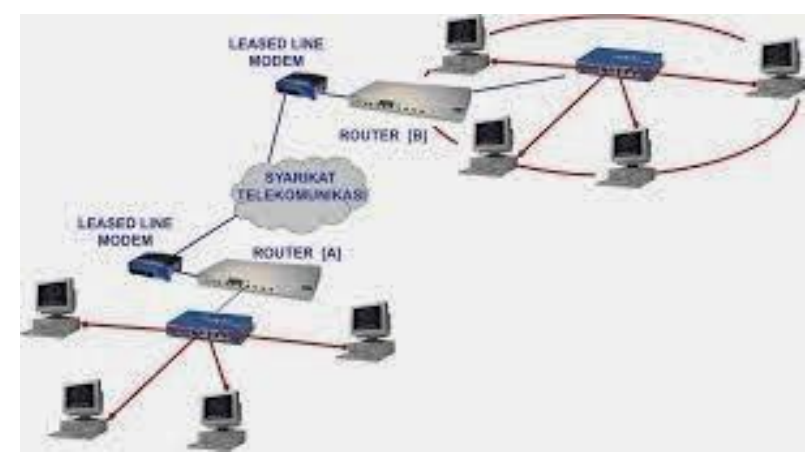

Gambar 6. Skema Jaringan MAN

Jaringan MAN adalah gabungan dari beberapa LAN. Jangkauan dari MAN ini antar 10 hingga $50 \mathrm{~km}$, MAN ini merupakan jaringan yang tepat untuk membangun jaringan antar kantor-kantor dalam satu kota antara pabrik/instansi dan kantor pusat yang berada dalam jangkauannya.

\section{Wide Area Network (WAN)}

WAN (Wide Area Network) merupakan jaringan komputer yang mencakup area yang besar sebagai contoh yaitu jaringan komputer antar wilayah, kota atau bahkan negara, atau dapat didefinisikan juga sebagai jaringan komputer yang membutuhkan router dan suatu saluran komunikasi publik. WAN digunakan untuk menghubungkan jaringan area lokal yang satu dengan jaringan lokal yang lain, sehingga pengguna atau komputer di lokasi yang satu dapat berkomunikasi dengan pengguna dan komputer di lokasi yang lain.

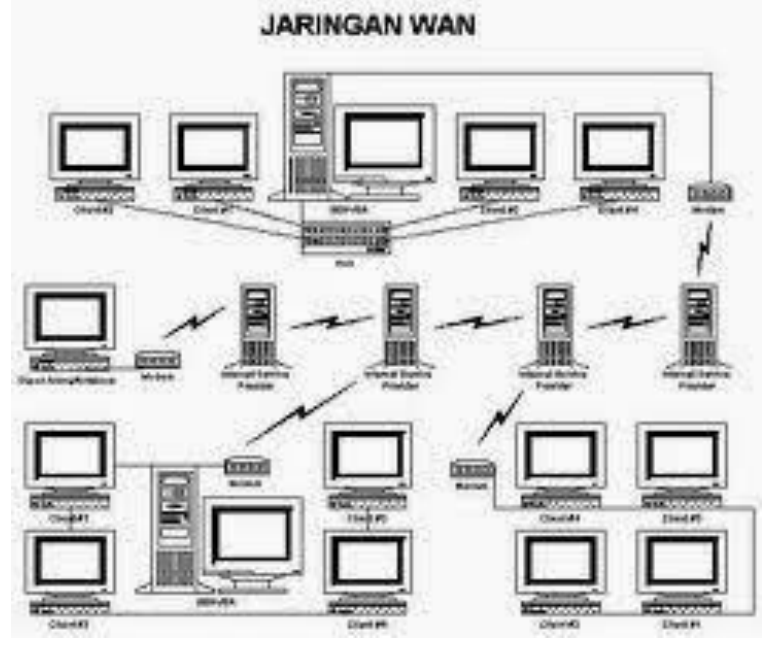

Gambar 7. Skema Jaringan WAN

\section{Quality of Service (QoS)}

QoS merupakan terminologi yang digunakan untuk mendefinisikan kemampuan suatu jaringan untuk menyediakan tingkat jaminan layanan yang berbeda-beda. Melalui QoS, seorang network administrator dapat memberikan prioritas traffic tertentu. Suatu jaringan, mungkin saja terdiri dari satu atau beberapa teknologi data link layer yang mampu diimplementasikan QoS, misalnya: Frame Relay, Ethernet, Token Ring, Point-to-Point Protocol (PPP), HDLC, X.25, ATM, SONET.

\section{Paramater QoS}

1. Availability: persentase hidupnya sistem atau subsistem telekomunikasi. Idealnya, availability harus mencapai $100 \%$. Nilai availability yang diakui cukup baik adalah 99,9999 \% (six nines), yang menunjukkan tingkat kerusakan sebesar 2,6 detik per bulan.

2. Throughput yaitu kecepatan (rate) transfer data efektif, yang diukur dalam bps. Header dalam paket data mengurangi nilai ini. Throughput dapat dihitung dengan melihat jumlah paket yang datang terhadap yang dikirim. 
3. Delay adalah waktu tunda saat paket yang diakibatkan oleh proses transmisi dari satu titik lain yang menjadi tujuannya.

\begin{tabular}{|l|l|}
\hline Range & Description \\
\hline $0-150 \mathrm{~ms}$ & $\begin{array}{l}\text { Acceptable for most user } \\
\text { application }\end{array}$ \\
\hline $150-400 \mathrm{~ms}$ & $\begin{array}{l}\text { Acceptable provided that } \\
\text { administrators are aware of } \\
\text { the transmission time and it's } \\
\text { impact on transmission } \\
\text { quality of user application }\end{array}$ \\
\hline$>400 \mathrm{~ms}$ & $\begin{array}{l}\text { Unacceptable for general } \\
\text { network planning purpose, it } \\
\text { is recoqnized that in some } \\
\text { exceptional cases this limit } \\
\text { will be exceeded. }\end{array}$ \\
\hline
\end{tabular}

Tabel 1. Standar ITU-T Untuk Delay

4. Packet loss / Error : Ukuran error rate dari transmisi packet data yang diukur dalam persen. Packet hilang (bit loss) yang biasanya dikarenakan buffer yang terbatas, urutan packet yang salah termasuk dalam error rate ini.

\begin{tabular}{|l|l|}
\hline Kategori Degredasi & Packet Loss \\
\hline Sangat bagus & $0 \%$ \\
\hline Bagus & $3 \%$ \\
\hline Sedang & $15 \%$ \\
\hline Jelek & $25 \%$ \\
\hline
\end{tabular}

Tabel 2. Standar ITU-T Untuk Packet Loss

5. Jitter: variasi delay yang diakibatkan oleh panjang queue dalam suatu pengolahan data dan reassemble paket-paket data di akhir pengiriman akibat kegagalan sebelumnya. Jitter merupakan masalah khas dari connectionless network atau packet switched network.

\begin{tabular}{|l|l|}
\hline Kategori Degredasi & Peak Jitter \\
\hline Sangat bagus & $0 \mathrm{~ms}$ \\
\hline Bagus & $75 \mathrm{~ms}$ \\
\hline Sedang & $125 \mathrm{~ms}$ \\
\hline Jelek & $225 \mathrm{~ms}$ \\
\hline
\end{tabular}

Tabel 3. Standar ITU-T Untuk Jitter

\section{Pengukuran QoS}

\section{Tool Wireshark}

Wireshark adalah tool yang ditujukan untuk penganalisisan paket data jaringan. Wireshark melakukan pengawasan paket secara waktu nyata (real time) dan kemudian menangkap data dan menampilkannya selengkap mungkin. Aplikasi Wireshark dapat berjalan di banyak platform, seperti Linux, Windows, dan Mac.

Wireshark dapat melakukan banyak hal sebagai tool dalam menganalisis suatu jaringan komputer. Adapaun Wireshark dapat digunakan sebagai berikut:

- Melakukan troubleshoot permasalahan jaringan

- Melakukan pengujian masalah keamanan

- Melakukan debugging implementasi protokol

- Belajar protokol jaringan

\section{Tool Speed Test}

Perhitungan yang dapat dilakukan setelah data ditransfer pada browser, maka beberapa hal yang perlu dicatat yaitu :

- Besar File yang dikirim dalam Byte

- Waktu mulai Transfer

- Waktu Selesai Transfer

Hasil pengujian speed test akan sangat tergantung pada kondisi jaringan dan berbagai hal lain yang sangat beragam, namun secara umum beberapa hal yang dapat mempengaruhinya yaitu :

- Lokasi Server yang dapat menentukan banyaknya hop yang harus dilalui paket data

- PC yang dapat melakukan proses download / transfer data yang lain

- Menggunakan aplikasi yang melakukan transfer data ke jaringan, khususnya yang satu subnet dengan koneksi anda ke internet

- Kualitas jaringan, khusunya pada transfer data analog yang sangat mungkin terpengaruh oleh noise, atau adanya interferensi elektromagnetis pada jaringan

- Apabila menggunakan modem 56KBps, secara real bandwidth maksimal yang mungkin didapat hanyalah 53 KBps, 
keterbatasan ini ada pada spesifikasi FCCnya

- Pembatasan besarnya bandwidth efektif pada jaringan, seperti pembatasan akses oleh Bandwidth management, Firewall dan sebagainya

- Cache Engine, yang memungkinkan didownload data dari cache, tidak secara langsung dari server

\section{Tool command : ping}

Ping digunakan untuk memeriksa suatu server bekerja dengan cara mengirimkan beberapa byte data dan menerima pantulannya. Jika pantulan diterima berarti komputer tujuan memberi respon dan menunjukkan bahwa komputer tujuan sedang beroperasi.

Setelah data ditransfer pada saat melakukan ping ke server, hasil ping tersebut digunakan untuk menentukan :

- Byte data yg dikirim

- Waktu yg dikirim

- TTL (Time to Live)

- Banyaknya paket yang dikirim

- Banyaknya paket yang diterima

- Average (rata-rata)

\section{Tool command : traceroute}

Untuk mengetahui karakteristik jalur internet / koneksi maka dilakukan performansi jaringan berdasarkan parameter bandwidth, latensi dan rugi-rugi data. Mekanisme traceroute dilakukan untuk mendapatkan informasi tentang jalur yang dilaluinya berdasarkan TTL (Time to Live).

\section{METODE PENELITIAN}

\section{Tempat dan Waktu Penelitian}

Penelitian ini dilakukan di ruang Laboratorium Multimedia Jurusan Teknik Elektro Fakultas Teknik Universitas Negeri Jakarta. Waktu penelitian dilakukan selama 1 bulan yaitu pada bulan Juni 2015.

\section{Deskripsi Setting Penelitian}

Dalam penelitian ini perangkat yang digunakan terdiri dari perangkat keras dan perangkat lunak. Perangkat keras yang digunakan antara lain: 2 PC sebagai server, 6 PC sebagai client, 9 kabel UTP, 1 buah router, dan 1 buah switch. Perangkat lunak yang digunakan antara lain: VLC Media Player dan Wireshark.

\section{Jenis Penelitian}

Jenis metode yang digunakan dalam penelitian adalah penelitian kualitatif, yaitu untuk mengetahui kualitas jaringan yang dilihat dari segi delay dan packet loss VLAN yang di dalamnya menerapkan Linux Terminal Server Project (LTSP) berdasarkan spesifikasi perangkat-perangkat yang ada dengan menggunakan data yang telah direkam oleh Wireshark.

\section{Hasil Penelitian}

\begin{tabular}{|l|l|l|l|}
\hline $\begin{array}{l}\text { Banyak } \\
\text { PC } \\
\text { Client }\end{array}$ & Delay $(\mathrm{ms})$ & $\begin{array}{l}\text { Packet } \\
\text { loss } \\
(\%)\end{array}$ & Keterangan \\
\hline 1 PC & 0.243169 & 0 & - \\
\hline 2 PC & 0.283265 & 0 & $\begin{array}{l}\text { Delay meningkat 4 } \\
\%\end{array}$ \\
\hline 3 PC & 0.364043 & 0 & $\begin{array}{l}\text { Delay } \\
\text { meningkat } \\
28,52 \%\end{array}$ \\
\hline
\end{tabular}

Tabel 4. Besar Delay dan Packet loss di VLAN 2

\begin{tabular}{|l|l|l|l|}
\hline $\begin{array}{l}\text { Banyak } \\
\text { PC } \\
\text { Client }\end{array}$ & Delay $(\mathrm{ms})$ & $\begin{array}{l}\text { Packet } \\
\text { loss } \\
(\%)\end{array}$ & Keterangan \\
\hline 1 PC & 0.096028 & 0 & - \\
\hline 2 PC & 0.162596 & 0 & $\begin{array}{l}\text { Delay } \\
\text { meningkat } \\
69,32 \%\end{array}$ \\
\hline 3 PC & 0.318237 & 0 & $\begin{array}{l}\text { Delay } \\
\text { meningkat } \\
95,72 \%\end{array}$ \\
\hline
\end{tabular}

Tabel 5. Besar Delay dan Packet loss di VLAN 3

\begin{tabular}{|l|l|l|l|}
\hline $\begin{array}{l}\text { Banyak } \\
\mathrm{PC}\end{array}$ & Delay $(\mathrm{ms})$ & $\begin{array}{l}\text { Packet } \\
\text { loss }\end{array}$ & Keterangan \\
\hline
\end{tabular}


http://doi.org/10.21009/pinter.1.2.1

\begin{tabular}{|l|l|l|l|}
\hline Client & & $(\%)$ & \\
\hline 1 PC & 0.145037 & 0 & - \\
\hline PC & 0.192177 & 0 & $\begin{array}{l}\text { Delay } \\
\text { meningkat } \\
32,5 \%\end{array}$ \\
\hline & & $\begin{array}{l}\text { Delay } \\
\text { meningkat } \\
28,96 \% \text { dan } \\
\text { Packet loss } \\
\text { mengalami } \\
\text { kenaikan 0,36 } \\
\%\end{array}$ \\
\hline
\end{tabular}

Tabel 6. Besar Delay dan Packet loss di Inter-VLAN 2

\begin{tabular}{|l|l|l|l|}
\hline $\begin{array}{l}\text { Banyak } \\
\text { PC } \\
\text { Client }\end{array}$ & Delay $(\mathrm{ms})$ & $\begin{array}{l}\text { Packet } \\
\text { loss } \\
(\%)\end{array}$ & Keterangan \\
\hline 1 PC & 0.138055 & 0 & $\begin{array}{l}\text { Tidak } \\
\text { Bermasalah }\end{array}$ \\
\hline 2 PC & 0.188913 & 0 & $\begin{array}{l}\text { Delay } \\
\text { meningkat } \\
36,84 \%\end{array}$ \\
\hline 3 PC & 0.266471 & 0 & $\begin{array}{l}\text { Delay } \\
\text { meningkat } \\
41,05 \%\end{array}$ \\
\hline
\end{tabular}

Tabel 7. Besar Delay dan Packet loss di Inter-VLAN 3

\section{Kesimpulan}

Pada akhirnya dalam penelitian ini dapat disimpulkan bahwa semakin banyak PC client yang dilayani oleh PC server pada jaringan VLAN yang menerapkan LTSP akan menurunkan kualitas jaringan dilihat dengan jelas dari parameter delay dan sedikit berpengaruh dari parameter packet loss. Besar delay dan packet loss secara berurutan berdasarkan setiap bertambah 1 PC client yang dilayani oleh PC server akan meningkat hingga mencapai sebesar $95,72 \%$ dan $0,36 \%$.

\section{DAFTAR PUSTAKA}

Irianto, K.D.; Fatmawati, S.; Ulya, N.K.; \& Nugroho, A. 2011. Perbandingan Kinerja 4 Model
Jaringan Komputer Hemat Biaya (Jaringan Standar, LTSP, Userful, dan N-Computing). Makalah seminar Nasional Teknologi Informasi \& Komunikasi Terapan 2011 (Semantik 2011), Universitas Muhammadiyah Surakarta, Solo, 2011.

Purbo, Onno W. 2006. PC Cloning Windows Pakai Linux LTSP. Yogyakarta: ANDI.

Zulhikam, A. 2011. Pengertian Jaringan Komputer, http://jaringankomputer.org/pengertianjaringan-komputer/, (diakses 18 Juni 2015 22:48 WIB).

Saiyan, M. 2013. Pengertian dan Definisi LAN, MAN, WAN, http://ikomputerpc.blogspot.com/2013/09/pe ngertian-jaringan-lan-wan-man-dan.html, (diakses 09 Juni 2015 03:04 WIB).

Sidin, Udin Sidik. 2010. Pemanfaatan VLAN dan Penghematan HOST dengan Metode VLSM. Volume 5, No. 2.

Hakim, L.A.R. 2009. Analisa dan Implementasi Quality of Service (QOS) Pada Jaringan JARDIKNAS (Jaringan Pendidikan Nasional). Yogyakarta: STMIK AMIKOM.

Kurniawan, Agus. 2012. Network Forensics Panduan Analisis \& Investigasi Paket Data Jaringan Menggunakan Wireshark. Yogyakarta: ANDI. 